\title{
Physicochemical atributes and quality of the Melipona scutellaris honey: comparison with Brazilian regulatory standards
}

\section{Atributos fisicoquímicos e qualidade do mel de Melipona scutellaris: comparação com os padrões regulatórios Brasileiros}

\author{
Vanessa de Fátima Lima Paiva Medeiros, Amália Cínthia Meneses Rego , Irami Araújo- \\ Filho, Vítor Brasil Medeiros, Aldo Cunha Medeiros \\ Study performed at Department of Surgery, Federal University of Rio Grande do Norte (UFRN), Brazil. \\ Financial support: none. \\ Conflict of interest: None. \\ Correspondence address: Department of Surgery, Federal University of Rio Grande do Norte, at Ave. Nilo \\ Peçanha 620, Natal, RN, Brazil, E-mail: cirurgex.ufrn@gmail.com \\ Submitted: October 10, 2015. Accepted, after review: December 12, 2015.
}

\section{ABSTRACT}

Objective: The aim this study was to compare the physicochemical characteristics of the honey of wild Melipona scutellaris with the standards determined by the technical regulations and honey quality of Ministry of Agriculture, Brazil. Methods: Honey of Melipona scutellaris was acquired from certified institution in Natal, RN, Brazil. The physicochemical analysis of honey was carried out so that all parameters were derived from the average of three replications. Moisture of the samples was determined by refractometer. The Hydroxymethylfurfural proof was determinined by the absorbance using a digital spectrometer, with a range of 200-1000 nm and band crossing $5 \mathrm{~nm}$. The ash content of the samples was determined in a muffle furnace. Digital pHmeter was used for measurement of $\mathrm{pH}$ and total acidity by the method of simple titration. Insoluble solids in water were determined by stove use. All these parameters were compared with those established by Technical Regulation of Ministry of Agriculture, Brazil, 2000, for honey identity and quality. Honey microbiological analysis was done using the blood agar and agar McConkey selective media. Results: The physicochemical analysis of the Melipona scutellaris honey demonstrated that all parameters were in accordance with the standards established by the Ministry of Agriculture, Brazil regulations, and could be considered of good quality for research and human consumption. The microbiological examination revealed that the honey had no bacterial contamination. Conclusion: Our findings suggest that the physicochemical composition of $M$. scutellaris honey is compatible with the Brazilian guidelines for the composition and quality of honey.

Keywords: Honey. Bee. Melipona scutellaris. Physicochemical caracterization. 


\section{RESUMO}

Objetivo: Comparar as características fisicoquímicas do mel da abelha silvestre Melipona scutellaris com os padrões determinados pelo Regulamento Técnico de Identidade e Qualidade do mel do Ministério da Agricultura, Brasil. Métodos: Mel de Melipona scutellaris foi adquirido de instituição certificada em Natal, RN, Brasil. A análise físico-química do mel foi feita a partir da média de três repetições. A umidade das amostras foi determinada por refratometria. A prova de hidroximetilfurfural foi realizada por determinação da absorvância da amostra, utilizando espectrômetro digital, na faixa de 200-1000 nm e banda $5 \mathrm{~nm}$. O teor de cinzas das amostras foi determinado em forno de mufla. Medidor de pH digital foi usado para a medição do $\mathrm{pH}$ e da acidez total através do método de titulação normal. Sólidos insolúveis em água foram determinados em estufa. Todos os parâmetros foram comparados com os estabelecidos no Regulamento Técnico do Ministério da Agricultura do Brasil, de 2000, para uso e qualidade do mel de abelha. Análise microbiológica foi feita usando os meios de cultura agar sangue e agar McConkey. Resultados: A análise físicoquímica do mel de Melipona scutellaris demonstrou que todos os parâmetros estão de acordo com os padrões estabelecidos pelos regulamentos do Ministério da Agricultura, Brasil, e pode ser considerado de boa qualidade para consumo humano e uso em pesquisa. A análise microbiológica revelou que o mel não tinha contaminação bacteriana. Conclusão: Nossos resultados sugerem que a composição físico-química do mel de $M$. scutellaris é compatível com as diretrizes brasileiras para a composição e qualidade do mel.

Descritores: Mel. Abelha. Melipona scutellaris. Caracterização fisicoquímica.

\section{INTRODUCTION}

Honey has been for centuries used as food, and in phythotherapy. One of the most important use is the prevention and limitation of bacterial infection derived largely from biochemical properties related to peroxide generation via glucose oxidase activity ${ }^{1}$, nonperoxide effects such as osmolarity, acidity, aromatic and phenolic acids, and other phytochemical compounds such as methylglyoxal ${ }^{2}$. Moreover, honey serves as a natural antioxidant and a rich source of minerals, carbohydrates, proteins, and vitamins with nutraceutical and probiotic properties ${ }^{3}$. The composition of honey depends basically of nectar production of each plant species, giving it specific characteristics according to the weather conditions. Among the existing sugars in honey, the monosaccharide is the most part, ranging from $85 \%$ 
Physicochemical atributes and quality of the Melipona scutellaris honey: comparison with Brazilian regulatory standards

VFLP, Medeiros et al

to $95 \%$ of its composition ${ }^{4}$. Another important parameter is the moisture that can influence the viscosity, specific gravity, maturity, crystallization, flavor, preservation and palatability ${ }^{5}$. After decrystallization, honey can form the hydroxymethylfurfural (HMF) which increases with temperature, storage time, and addition of invert sugar. It is also affected by acidity, $\mathrm{pH}$, water and minerals ${ }^{6}$. The analysis of honey requires special and sophisticated methods such as those performed using spectrophotometric assays, particularly gas chromatography-mass spectrometer, liquid chromatography-mass spectrometer, nuclear magnetic resonance, etc. These techniques are used to assess contents of molecules and elucidate the structure of active molecules ${ }^{7}$.

Brazilian honeys have a wide range of color which can influence consumer preference, in most cases for the product looks. The honey color is correlated with its floral origin, processing storage, climatic factors during the nectar flow, and the temperature at which the honey matures ${ }^{8}$. The electrical conductivity can be used as a supplementary method to determine the botanical origin of the honey and has correlation with the ash content, $\mathrm{pH}$, acidity, minerals, in addition to proteins and other substances found in honey ${ }^{9}$. International and Brazilian regulations about honey quality are available ${ }^{10,11}$.

This research, developed with honey samples of Melipona scutellaris, a wild bee from Brazilian semi-arid region, aimed to compare their physicochemical characteristics to the specific Brazilian regulations for honey, which establishes its quality control.

\section{METHODS}

\section{Honey physicochemical analysis}

Honey of Melipona scutellaris acquired from certified institution in Natal, RN, Brazil was used. The physicochemical analysis of honey was carried out so that all parameters were derived from the average of three replications. Moisture of the samples was determined by refractometer. The Hydroxymethylfurfural proof was performed to verify the possibility of tampering by adding sugar, improper storage or overheating, by determining the absorbance of the sample, using a digital spectrometer, with a range of $200-1000 \mathrm{~nm}$ and band crossing $5 \mathrm{~nm}$. The ash content of the samples was determined in a muffle furnace. A digital pHmeter was used for measurement of $\mathrm{pH}$ and total acidity was measured by simple titration. Insoluble solids in water were determined by stove use. All these parameters were compared with those established by the Technical Regulation of Ministry of Agriculture, Brazil, 
Physicochemical atributes and quality of the Melipona scutellaris honey: comparison with Brazilian regulatory standards

VFLP, Medeiros et al

2000, for honey Identity and Quality. Honey microbiological analysis was done using the blood agar and agar McConkey selective media.

\section{RESULTS}

The physicochemical analysis of the Melipona scutellaris honey demonstrated that all parameters were in accordance with the standards established by the Regulations of Ministry of Agriculture, Brazil 2000, and could be considered of good quality for human consumption and research (Table 1). The microbiological examination revealed that the honey had no contamination with Gram-positive and Gram-negative bacteria.

Table 1 - Parameters of physicochemical analysis of Melipona scutellaris (uruçu) honey compared with those established by the Regulations of Ministry of Agriculture, Brazil $^{11}$.

\begin{tabular}{ccccccc}
\hline Samples & $\begin{array}{c}\text { Humidity } \\
(\%)\end{array}$ & $\begin{array}{c}\mathrm{HMF} \\
(\mathrm{mg} / \mathrm{Kg})\end{array}$ & $\mathrm{pH}$ & $\begin{array}{c}\text { Acidity } \\
(\mathrm{meq} / \mathrm{kg})\end{array}$ & $\begin{array}{c}\text { Ash } \\
(\%)\end{array}$ & $\begin{array}{c}\text { Insoluble } \\
\text { solids }(\%)\end{array}$ \\
\hline Uruçu honey & 18.06 & 23.90 & 3.85 & 41.66 & 0.1 & 0.06 \\
\hline $\begin{array}{c}\text { Ministry of } \\
\text { Agriculture, }\end{array}$ & $\begin{array}{c}\text { Maximum } \\
20\end{array}$ & $\begin{array}{c}\text { Maximum } \\
40\end{array}$ & $\begin{array}{c}3,3- \\
4,6\end{array}$ & $\begin{array}{c}\text { Maximum } \\
50\end{array}$ & $\begin{array}{c}\text { Maximum } \\
0.6\end{array}$ & $\begin{array}{c}\text { Maximum } \\
0.1\end{array}$ \\
\hline \begin{tabular}{c} 
(Brazil)Regulations \\
\hline HMF hydroxym
\end{tabular} & & & & &
\end{tabular}

HMF, hydroxymethylfurfural

\section{DISCUSSION}

In this study, we studied the physicochemical composition of Melipona scutellaris honey, a wild stingless bee, known as Uruçu, common in semi-arid region of Northeast Brazil. Its honey has been used empirically in popular medicine to treat respiratory diseases, skin and soft tissue diseases, and little is known about its physicochemical composition. Microbiological and physicochemical analysis of Melipona scutellaris honey revealed that it is in accordance with the quality standards established by the Ministry of Agriculture, Brazil. According to Brazilian rules for use of honey in humans, it should be ensured good origin and safety of physicochemical and microbiological point of view, combined with being cost-effective ${ }^{11}$.

Honey is a natural supersaturated sugar solution, which is mainly composed of a complex mixture of carbohydrates. In addition to carbohydrate content, it also 
Physicochemical atributes and quality of the Melipona scutellaris honey: comparison with Brazilian regulatory standards

VFLP, Medeiros et al

contains approximately $20 \%$ water as well as minor but important constituents such as proteins, enzymes (invertase, glucose oxidase, catalase, and phosphatases), amino acids, organic acids (gluconic acid, acetic acid), lipids, vitamins (ascorbic acid, niacin, pyridoxine), volatile chemicals, phenolic acids, flavonoids, carotenoid-like substances, and minerals ${ }^{12,13}$. The composition of honey can be variable and is primarily dependent on its floral, geographical, and entomological source. Certain external factors, such as seasonal and environmental factors and processing, also play important roles ${ }^{14.15}$. The quality of honey is determined by its sensorial, chemical, physical and microbiological characteristics ${ }^{16}$. The major criteria of interest are moisture content, electrical conductivity, ash content, reducing and non-reducing sugars, free acidity, diastase activity and hydroxymethylfurfural content. The comparative physicochemical characteristics of honeys from other regions of the world have been extensively studied ${ }^{17}$, but data on regional honey from Melipona scutellaris are scarce.

Study by Brazilian researchers indicated that the Apis mellifera honey is composed of about $40 \%$ fructose, $20 \%$ water, amino acids, vitamins (niacin, pyridoxine and thiamine), enzymes (diastase, invertase, catalase and glucose oxidase ), hydrogen peroxide, and minerals (potassium, iron, magnesium, phosphorus, copper, zinc and calcium ${ }^{18}$. Among the related properties of honey, antibacterial activity is very important: honey is a supersaturated solution with strong osmotic activity, the $\mathrm{pH}$ is between 3.2 and 4.5 , and this acidity is sufficient to inhibit the growth of many microorganisms. By the way, the $\mathrm{pH}$ of $M$. scutellaris honey was 3.85. Hydrogen peroxide produced by the glucose-oxidase is certainly the most important antibacterial component of honey and several other phytochemicals and immunochemical factors have been avaluated ${ }^{19,20}$. A study conducted in our laboratory with the use of honey Melipona subnitida (Jandaíra) showed significant antimicrobial effect in infected wounds of skin $^{21}$.

In conclusion, our findings suggest that the physicochemical composition of Melipona scutellaris honey is compatible with the Brazilian guidelines for the composition and quality of honey. So, it is adequate for human consumption and research. 


\section{REFERENCES}

1. Brudzynski K. Effect of hydrogen peroxide on antibacterial activities of Canadian honeys. Can. J. Microbiol. 2006; 52: 1228-37.

2. Lee $\mathrm{H}$, Churey JJ, Worobo RW. Antimicrobial activity of bacterial isolates from different floral sources of honey. Int J Food Microbiol. 2008;126: 240-4.

3. Begum S B, Roobia RR, Karthikeyan M, Murugappan R M. Validation of nutraceutical properties of honey and probiotic potential of its innate microflora. Food Sci Technol. 2015;60: 743-50.

4. Del Campo G, Zuriarrain J, Zuriarrain A, Berregi I. Quantitative determination of carboxylic acids, amino acids, carbohydrates, ethanol and hydroxymethylfurfural in honey by (1)H NMR. Food Chem. 2016;196:1031-9.

5. Sereia MJ, Alves EM, Toledo VA, Marchini LC, Serine ES, Faquinello P, Almeida Dd, Moreti AC. Physicochemical characteristics and pollen spectra of organic and non-organic honey samples of Apis mellifera $L$. An Acad Bras Cienc. 2011;83:1077-90.

6. Pasini F, Gardini S, Marcazzan GL, Caboni MF. Buckwheat honeys: screening of composition and properties. Food Chem. 2013;141:2802-11.

7. Bertoncelj J, Dobersek U, Jamnik M, Golob T. Evaluation of the phenolic content, antioxidant activity and colour of Slovenian honey. Food Chem 2007;105: 822-8.

8. Kadar M, Juan-Borrás M, Carot JM, Domenech E, Escriche I. Volatile fraction composition and physicochemical parameters as tools for the differentiation of lemon blossom honey and orange blossom honey. J Sci Food Agric. 2011;91:2768-76.

9. Kumar P, Sindhu RK, Narayan S, Singh I. Honey collected from different floras of Chandigarh Tricity: a comparative study involving physicochemical parameters and biochemical activities. J Diet Suppl. 2010;7:303-13.

10. Bogdanov S, Lüllmann C, Martin P, Von Der Ohe W, Russmann H, Vorwohl G, et al. Honey quality, methods of analysis and international regulatory standards: review of the work of the International Honey Commission. Mitt Lebensm Hyg. 1999;90:108-25.

11. BRASIL. Ministério da Agricultura. Instrução normativa 11, de 20 de outubro de 2000. Regulamento técnico de identidade e qualidade do mel. Diário Oficial, Brasília, 20 de outubro de 2000, Seção 1, p. 16-17.

12. Blasa M, Candiracci M, Accorsi A, Piacentini MP, Albertini MC, Piatt E: Raw millefiori honey is packed full of antioxidants. Food Chem. 2006;97:217-22.

13. Saxena S, Gautam S, Sharma A: Physical, biochemical and antioxidant properties of some Indian honeys. Food Chem. 2010;118:391-7. 
14. Gheldof N, Xiao-Hong $\mathrm{W}$, Engeseth $\mathrm{N}$ : Identification and quantification of antioxidant components of honeys from various floral sources. J Agric Food Chem. 2002;50:5870-7.

15. Guler A, Bakan A, Nisbet C, Yavuz O: Determination of important biochemical properties of honey to discriminate pure and adulterated honey with sucrose (Saccharum officinarum L.) syrup. Food Chem. 2007;105:1119-25.

16. Alvarez-Suarez JM, Tulipani S, DÃaz D, Estevez Y, Romandini S, Giampieri F, Damiani E, Astolfi P, Bompadre S, Battino M: Antioxidant and antimicrobial capacity of several monofloral Cuban honeys and their correlation with color, polyphenol content and other chemical compounds. Food Chem Toxicol. 2010; 48:2490-9.

17. Azeredo LC, Azeredo MAA, Souza SR, Dutra VML: Protein contents and physicochemical properties in honey samples of Apis mellifera of different floral origins. Food Chem. 2003; 80:249-54.

18. Marchini LC, Moreti ACCC, Otsuk IP. Análise de agrupamento, com base na composição físico-química, de amostras de méis produzidos por Apis mellifera $\mathrm{L}$ no Estado de São Paulo. Ciênc Tecnol Aliment. 2005; 25: 8-17.

19. Jeddar A, Kharsany A, Ramsaroop UG, Bhamjee A, Haffejee IE, Moosa A. The antibacterial action of honey. An in vitro study. S Afr Med J. 1985;67:257-8.

20. Wahdan HA. Causes of the antimicrobial activity of honey. Infection. 1998; 26:2631.

21. Alves DFS, Cabral Júnior FC, Cabral PPAC, ; Oliveira Junior RM, Rego ACM, Medeiros AC. Efeitos da aplicação tópica do mel de Melipona subnitida em feridas infectadas de ratos. Rev Col Bras Cir. 2008;35:188-93. 